\title{
Hair Collar Sign and Viral Infection in Pregnancy: Two Clinical Cases
}

Tripaldi Clelia ${ }^{1^{*}}$, Baldoni Irene ${ }^{2}$, and Pisconti Cosimo Lucio ${ }^{1}$

${ }^{1}$ UOSVD Neonatologia e Pediatria Ambulatoriale, Ospedale di Putignano, ASL BA, Italy

${ }^{2}$ UOC Pediatria e Neonatologia, Ospedale di Jesi, Area Vasta 2, ASUR Marche, Italy

*Corresponding author: Tripaldi Clelia, UOSVD Neonatologia e Pediatria Ambulatoriale, Ospedale di Putignano, ASL BA, Italy, Tel: +39080883046; E-mail: cleliatripaldi@tiscali.it

Rec date: September 01, 2015; Acc date: September 14, 2015; Pub date: September 24, 2015

Copyright: (c) 2015 Clelia T. This is an open-access article distributed under the terms of the Creative Commons Attribution License, which permits unrestricted use, distribution, and reproduction in any medium, provided the original author and source are credited.

\begin{abstract}
Hair collar sign is a rare malformation of the scalp, often associated with impairment of the central nervous system such as encephaloceles, meningoceles, and heterotopic brain tissue. We describe the cases of two male neonates, with maternal history positive for viral infections in pregnancy and no associated malformations of the nervous system, but coexistence of cutaneous plan nevi.
\end{abstract}

Keywords: Hypertrichosis; Pregnancy; Nevus; Skin

\section{Introduction}

Aplasia cutis is a condition in which localized or generalized areas of skin are absent at birth. It may be associated with many genetic diseases or syndromes, and its etiology is unknown. It probably is not attributable to a single cause but to a combination of genetic or teratogen factors compromising vascularization of the skin. A ring of hypertrichosis around an area of aplasia cutis often set on the vertex, is called "hair collar sign" and raises suspicion of ectopic neural tissue and an underlying defect of the skull. It is often associated with encephaloceles, meningoceles, and heterotopic brain tissue. The skin and the nervous system are both derived from ectoderm. Separation of neural ectoderm from epithelial ectoderm occurs concurrently with the closure of the neural tube. This chronologic association may explain the cutaneous anomalies often found overlying neural tube defects. The increased incidence of lesions on the vertex is considered to be the result of a point of maximum tensile forces during rapid brain growth, between 10-18 weeks of gestation.

\section{Clinical cases}

We describe the cases of two male late preterm neonates born in our Hospital.

The first one, born from spontaneous delivery after normal pregnancy, mother 27 years old, gestational age $36 \mathrm{wks}$, weight at birth $2.700 \mathrm{Kg}$, good conditions for all the time of hospitalization. The baby appeared a circular scalp lesion on the vertex, $0.5 \mathrm{~mm}$ of diameter, with curly long hair encircling the area, (Figure 1) without any other physical abnormalities. CT scan of the skull showed no abnormal communication between the skin and the brain. The only anomaly he showed was a cutaneous plan nevus on the left thigh, of diameter $1 \times 2$ $\mathrm{cm}$ and irregular shape. His mother developed the so-called "Handsfeet-mouth sickness" from Cocksackie Virus during the sixteenth week of pregnancy. All prenatal ecographic examinations showed normal features, and maternal antibodies complex TORCH were negative. The same baby was evaluated at 12 months of age. He was in very good conditions, with normal growth and neurological development. At follow-up revaluation, the scalp lesion was exactly the same, while the plan nevus increased its extension until $1.5 \times 2.5 \mathrm{~cm}$.

The second neonate, first child, born from spontaneous delivery after normal pregnancy, gestational age $36 \mathrm{wks}+3$ days, mother 39 years with negative complex TORCH antibodies, weight at birth 2.385 $\mathrm{Kg}$, no other physical anomalies, showed circular scalp lesion on the vertex with $0.5 \mathrm{~mm}$ of diameter (Figure 2) and plan nevus on right leg. CT examination did not show any anomaly or abnormal communication between skin and brain. His mother contracted a viral infection around the fourteenth week of gestational age, likely due to influenza virus. At follow-up examination at one year age, the baby was in excellent conditions, with sign collar size unchanged, and plan nevus larger than one centimeter.

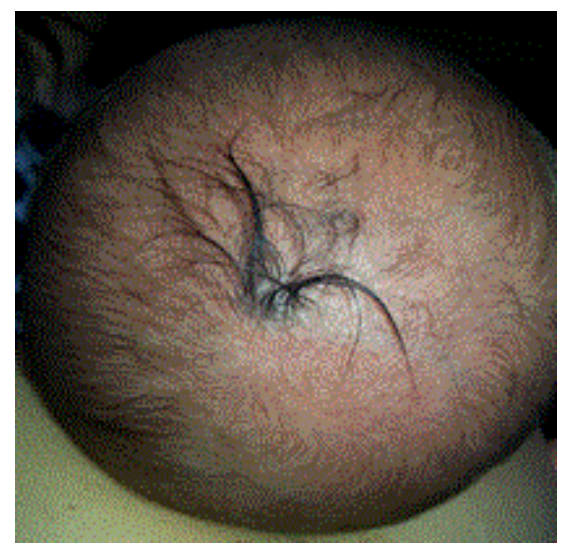

Figure 1: Circular scalp lesion.

\section{Discussion}

The existence of scalp lesion in these neonates may be connected to viral infection at the beginning of second trimester of pregnancy. Melanocytic nevi and heterotopic brain tissue that is found in areas of aplasia cutis, have a common derivation from the neural crest cells. In fact, during the first three months of development, the epidermis is 
Citation: Clelia T, Irene B, Lucio PC (2015) Hair Collar Sign and Viral Infection in Pregnancy: Two Clinical Cases. J Neonatal Biol 4: 197. doi:

Page 2 of 2

invaded by cells originating from the neural crest. Viruses have a pronounced tropism for cells of the neural tube that around the beginning of the fourth month start their final migration. At this stage, an insult outside such as viral infection, may be the original noxa for the incomplete formation of localized areas of skin. In both patients there were no other injuries associated with central nervous system or of the skull, nor other organs or systems. Difficult to understand the link between sign collar and plan nevi, findings frequently found in many newborns.

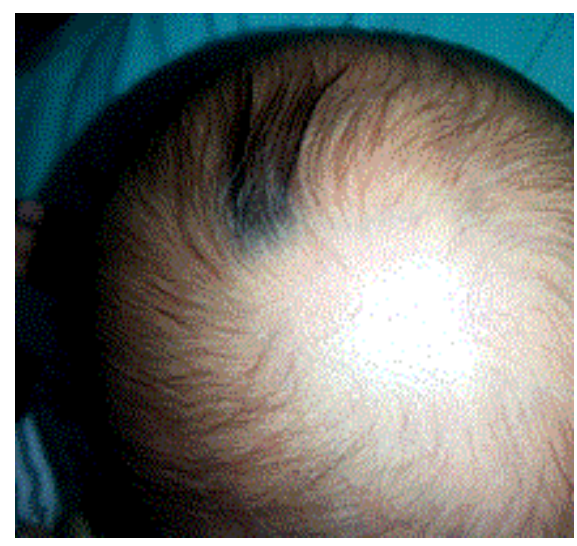

Figure 2: Scalp lesion.

\section{Conclusion}

The interest of this case report is the singular relation between maternal viral diseases in the fourth month of pregnancy, prematurity, sign collar and nevus plan, as well as male sex in both cases. This association could be the starting point for the reporting of other similar cases so far reported in the literature.

\section{References}

1. Cheraghi N, Delano S, Csikesz C, Dundamadappa S, Wiss K (2014) Sinus pericranii with a hair collar sign. Pediatr Dermatol 31:397-398.

2. Garcia-Romero MT, Narvóez-Rosales, VHojyo-Tomoka MT (2011) Bullous aplasia cutis congenita: case report and review of the literature. Indian J Dermatol 3: 337-338.

3. Held I, Rose C, Hamm H, Fölster-Holst R (2011) The hair collar sign - a possible indication of cranial dysraphism.J Dtsch Dermatol Ges 9: 136-138.

4. Stevens CA, Galen W (2008) The hair collar sign.Am J Med Genet A 146A: 484-487.

5. Harrington BC (2007) The hair collar sign as a marker for neural tube defects. Pediatr Dermatol 24: 138-140.

6. Roche-Gamón E, Febrer-Bosch I, Alegre de Miquel V (2007) [Hair collar sign associated with scalp aplasia cutis congenita]. Actas Dermosifiliogr 98: 442-443.

7. Herron MD, Coffin CM, Vanderhooft SL (2005) Vascular stains and hair collar sign associated with congenital anomalies of the scalp.Pediatr Dermatol 22: 200-205.

8. Drolet BA, Clowry L Jr, McTigue MK, Esterly NB (1995) The hair collar sign: marker for cranial dysraphism. Pediatrics 96: 309-313. 